\title{
Case study: analysis of a highwall toppling failure and development of a successful mine re-entry plan using RS2, RocFall and Dan-W at a coal mine in Canada
}

\author{
C Clayton Tetra Tech Canada Inc., Canada \\ A Jackson Tetra Tech Canada Inc., Canada \\ J Price Tetra Tech Canada Inc., Canada
}

A Bidwell Teck Coal Limited, Canada

D Elmo The University of British Columbia, Canada

\begin{abstract}
A highwall failure at an open pit coal mine in western Alberta, Canada occurred on 9 July 2017. A larger failure occurred on 5 August 2017. Radar monitoring successfully identified this second failure prior to the event. The initial assessment of the failure mechanism suggested toppling of steep bedding. The stratigraphy of the highwall consists of thinly to thickly bedded sedimentary strata dipping south at angles of about 65 to $70^{\circ}$ into the wall. Neither failure resulted in injury or damage to vehicles or infrastructure, however, mining of the pit was suspended pending an assessment of the wall stability and the development of an appropriate re-entry mining plan.
\end{abstract}

Following the failure, two principal hazards remained. The eastern portion of the highwall slope was characterised by potential rockfall hazards beneath the failed slope area. The western portion of the slope was characterised by a larger rock mass which had not failed and presented a toppling hazard and potential debris runout hazard. Prior to re-entry into the pit, a re-entry strategy was developed to allow mining of the remaining coal to be completed safely. The overall stability of the slope geometry was evaluated using RS2 ${ }^{\text {TM }}$ finite element modelling methods, and re-entry strategies involving crest unloading to reduce the remaining failure hazard were assessed. A rockfall analysis for the eastern portion of the slope was completed using RocFall ${ }^{T M}$, calibrated against observed conditions. A runout analysis of the western portion of the slope was completed using Dan-W $W^{T M}$, calibrated against observed conditions. The results of the rockfall and runout analyses were used to design appropriately sized berms located at the toe of the slope. The re-entry plan incorporated the rockfall berm design, a rockfall runout setback distance for the berm, and crest unloading on two sequential single benches. The mitigation strategy was supplemented by radar monitoring. This paper summarises the analyses that were completed to develop a safe, fit-for-purpose re-entry strategy that has since been successfully implemented.

Keywords: slope failure, finite element analysis, rockfall analysis, runout analysis, DAN-W, RocFall, RS2

\section{Introduction}

A coal mine located in the foothills of the Rocky Mountains in west-central Alberta consists of a series of open pits mined using conventional truck and shovel equipment. The open pits are generally oriented along strike and are relatively narrow and long. Mining is undertaken on $15 \mathrm{~m}$ single working benches. Highwalls and endwalls are mined using a standard benched wall design approach and are typically developed in a $30 \mathrm{~m}$ high double bench configuration wherever the geotechnical conditions allow. Figure 1 shows the project location. 


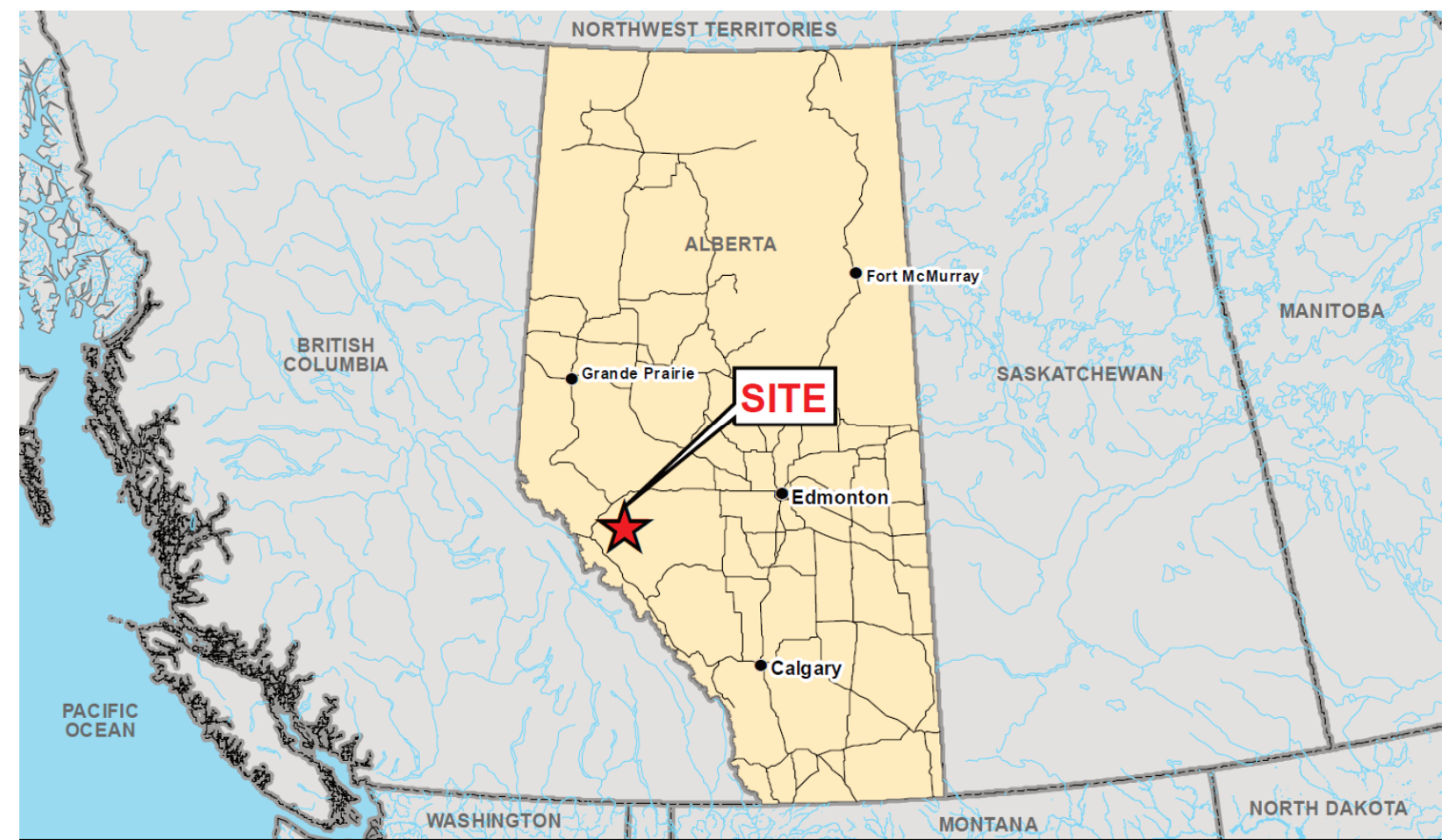

Figure 1 Project location

A failure of the south highwall of the H3 Pit occurred on 9 July 2017. The highwall was approximately $60 \mathrm{~m}$ high. Routine due diligence radar monitoring of this section of highwall was established three days prior to the initial failure, however, the baseline data collected up to 9 July 2017 was insufficient to predict the failure as the time did not allow for a progressive trend to be identified. A subsequent failure occurred on 5 August 2017 and the radar was successful in detecting early signs of the developing failure. Neither failure resulted in injury or damage to vehicles or infrastructure. Mining of the pit was suspended pending an assessment of the wall stability, and the development of an appropriate and safe re-entry mining plan. Figure 2 shows the extents of the failure.

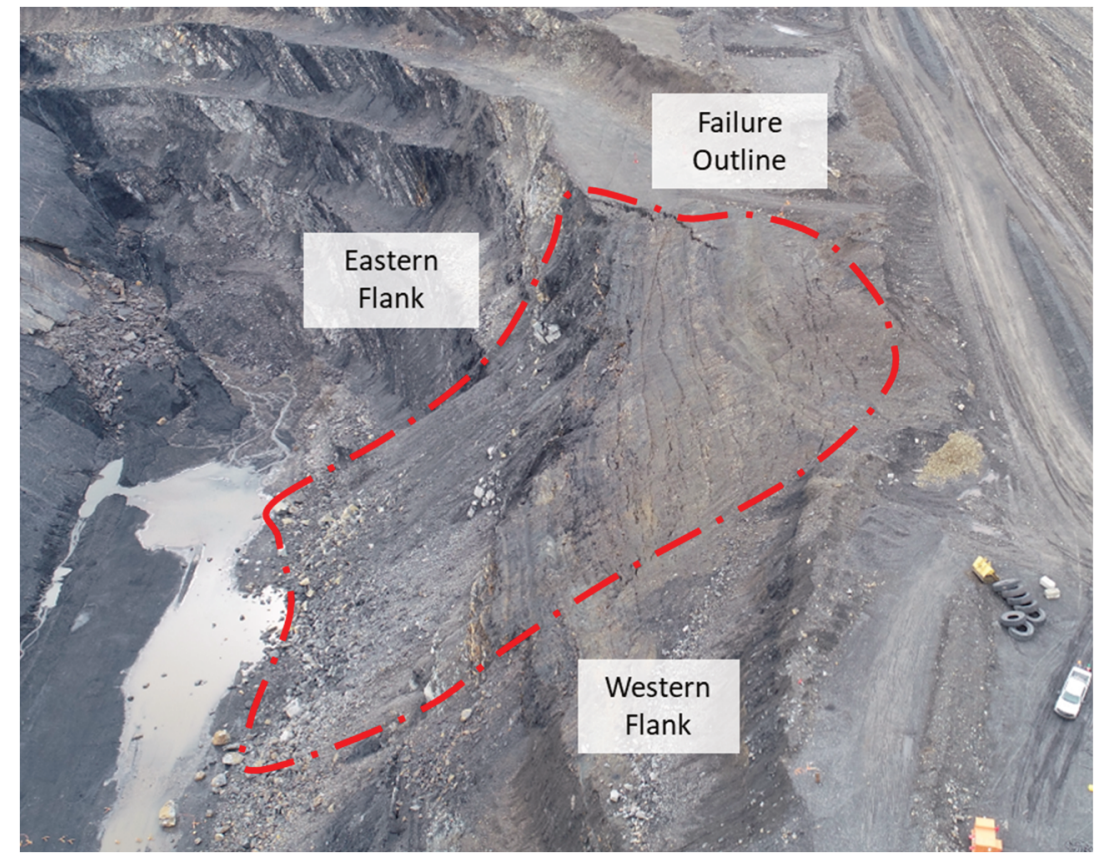

Figure 2 View of $\mathrm{H} 3$ pit failure extents 
Re-entry strategies involving material unloading above the failed section to reduce the potential for additional mining to trigger further movement were evaluated using finite element modelling software RS2 $^{\text {TM }}$ (Rocscience Inc. 2019). The size and location of a containment berm on the pit floor was evaluated using RocFall $^{\mathrm{TM}}$ (Rocscience Inc. 2018) and Dan-W $\mathrm{W}^{\mathrm{TM}}$ (Hungr 2003) commercial software.

\section{Geology of the south highwall}

The general stratigraphy consists of interbedded sediments from the Lower Cretaceous era, consisting of sandstone, siltstone, shale, mudstone, limestone and conglomerate. The main coal seam generally ranges in true thickness from 8 to $9 \mathrm{~m}$ but can be as thick as $30 \mathrm{~m}$. Underlying the main coal seam is a competent layer of sandstone, which forms the footwall slopes. The interbedded sediments above the main coal seam contain thinner uneconomic coal seams ranging in thickness from 1.5 to $3 \mathrm{~m}$. In the south highwall of the pit, the interbedded sediments dip into highwall at angles that vary between 50 to $65^{\circ}$. Two parallel north-dipping faults with approximately $14 \mathrm{~m}$ separation strike obliquely into the wall at the toe of the failed slope. The faults dip at approximately $65^{\circ}$ to the north and the rock between the faults is of reduced rock mass quality. Figure 3 illustrates the stratigraphic column for the site.

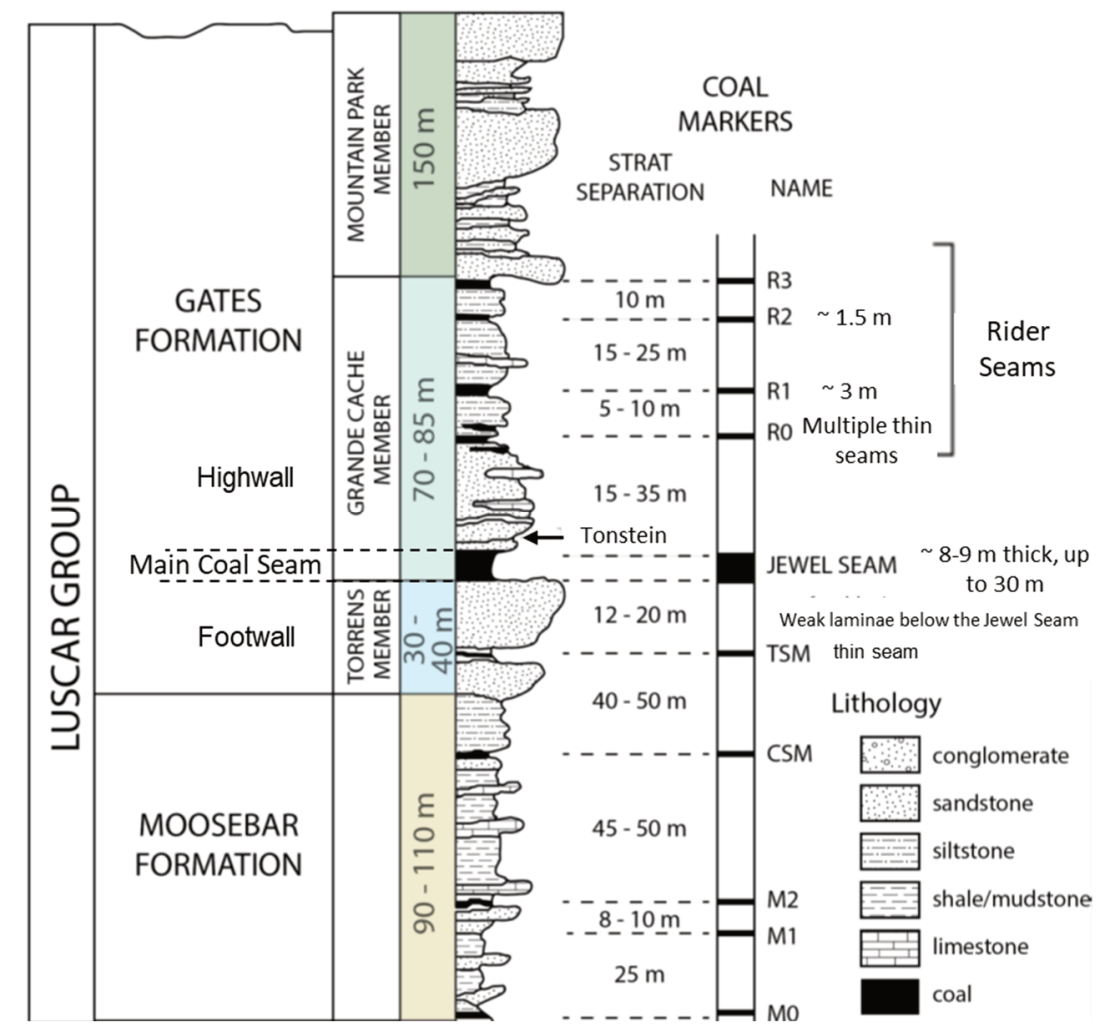

Figure 3 Stratigraphic column

\section{Failure sequence}

The initial failure of the south highwall slope occurred on 9 July 2017 during mining on the 1,820 m platform. As noted above, routine slope stability monitoring with a radar had been started on 6 July 2017, three days prior to the initial failure, but the period over which the data were collected was insufficient to predict it. Pit camera footage that captured the 9 July failure showed that mining at the toe of the failure area triggered an initial failure of the weak inter-fault material, leading to a reduction of toe support and confinement and subsequent toppling of the $30 \mathrm{~m}$ high bench face above. A subsequent failure followed on 5 August 2017. Deformation of the slope prior to failure was identified using a radar system installed on the opposite side of the pit. 
Figure 4(a) illustrates the general profile through the failed slope showing the approved pit design profile and the as-mined topography to early July 2017. Figure $4(\mathrm{~b})$ is a photograph of the development of obsequent fault scarps along bedding planes at the crest of the slope following the August 2017 failure.
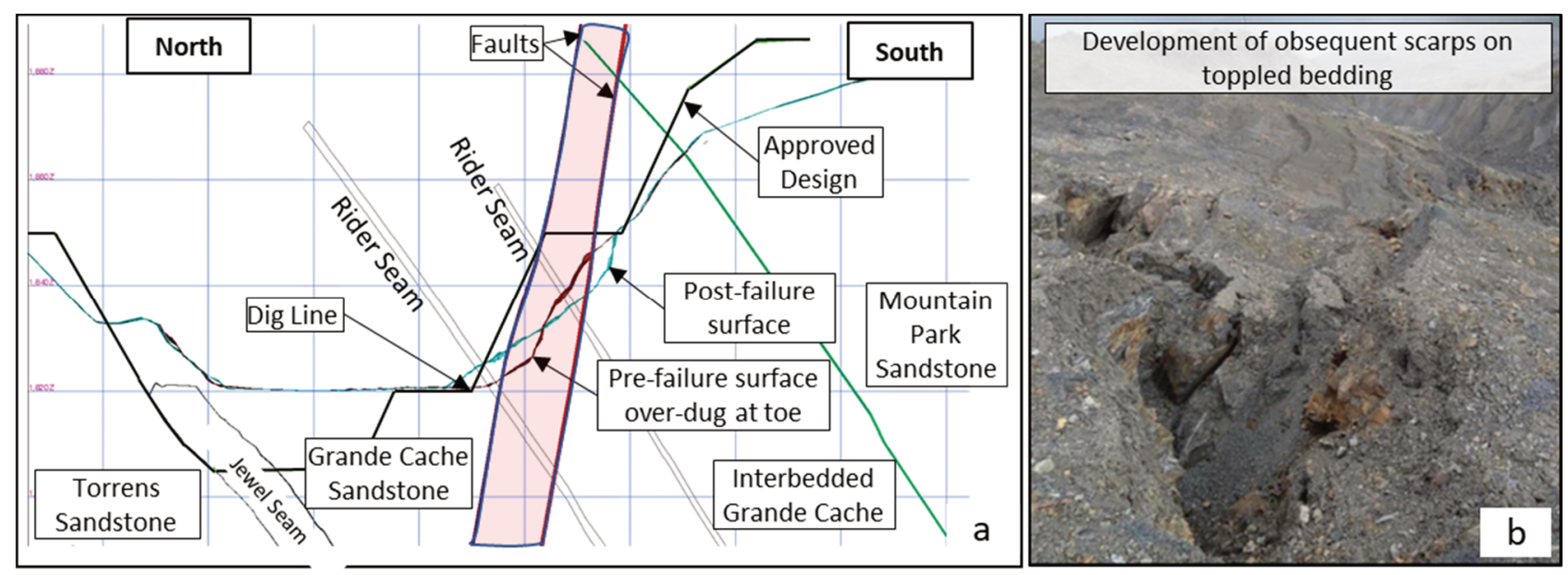

Figure 4 (a) General slope profile pre- and post-failure; and (b) Obsequent fault scarp development

\section{$4 \quad$ Remaining hazards to re-entry}

Following the failure, two hazards to re-entry remained. The eastern portion of the failed highwall was characterised by potential rockfall hazards (east rockfall area). The western portion of the failed highwall was characterised by a larger toppling rock mass which had not fully failed, leaving a potential mass runout hazard (west toppling area). Figure 5 shows the two hazard areas.

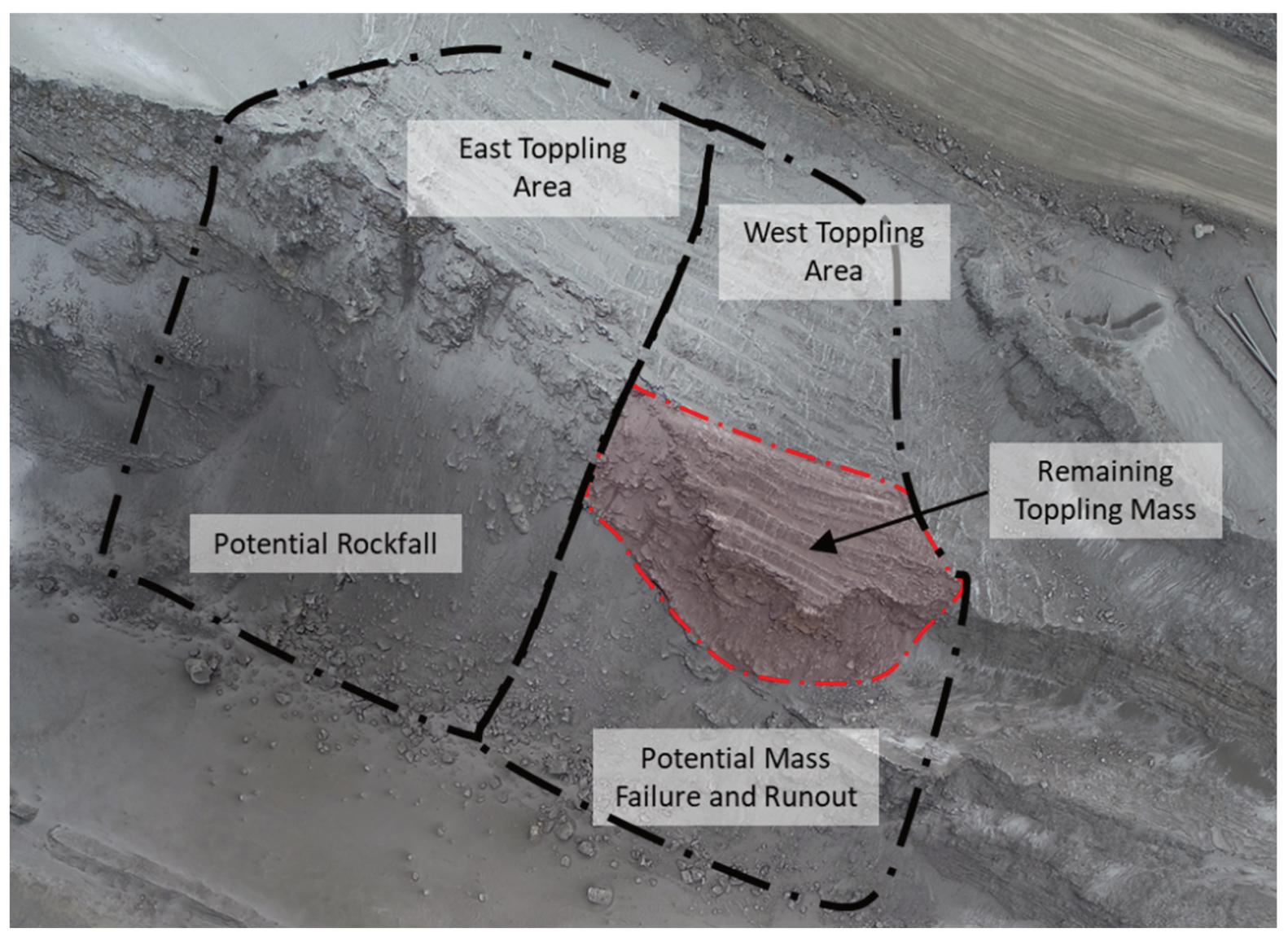

Figure 5 Remaining hazards to mining re-entry 


\section{Data review}

There were no previous geotechnical or hydrogeological investigations done in the H3 Pit area. Consequently, input parameters for modelling were derived from a review of available supplementary data, and from experience with similar rock types and structure at other pits in the project area. The available data included photographs and drone video of the toppling area, meteorological data from a nearby site, radar data plots, dip meter data from exploration drilling, and field mapping.

\subsection{Interpretation of hydrogeological conditions}

There are no piezometers installed behind the pit crest, and a conceptual hydrogeological model was developed based on empirical observations of seepage face locations on the pit walls, and with consideration of the structural conditions and expected relative permeabilities of the various rock types in the stratigraphic sequence. The locations of seepage faces observed in the pit suggest there are elevated pore pressures behind the wall, which are likely due to the lower permeability coal Rider Seams acting as aquitards restricting water flow. Elevated pore pressures might have existed prior to failure.

\subsection{Meteorological conditions}

Data from a nearby weather monitoring station were reviewed. A period of heavy rainfall occurred approximately one week prior to the 9 July failure; two days of rainfall were recorded on 3 and 4 August 2017 preceding the 5 August 2017 failure, as shown in Figure 6.

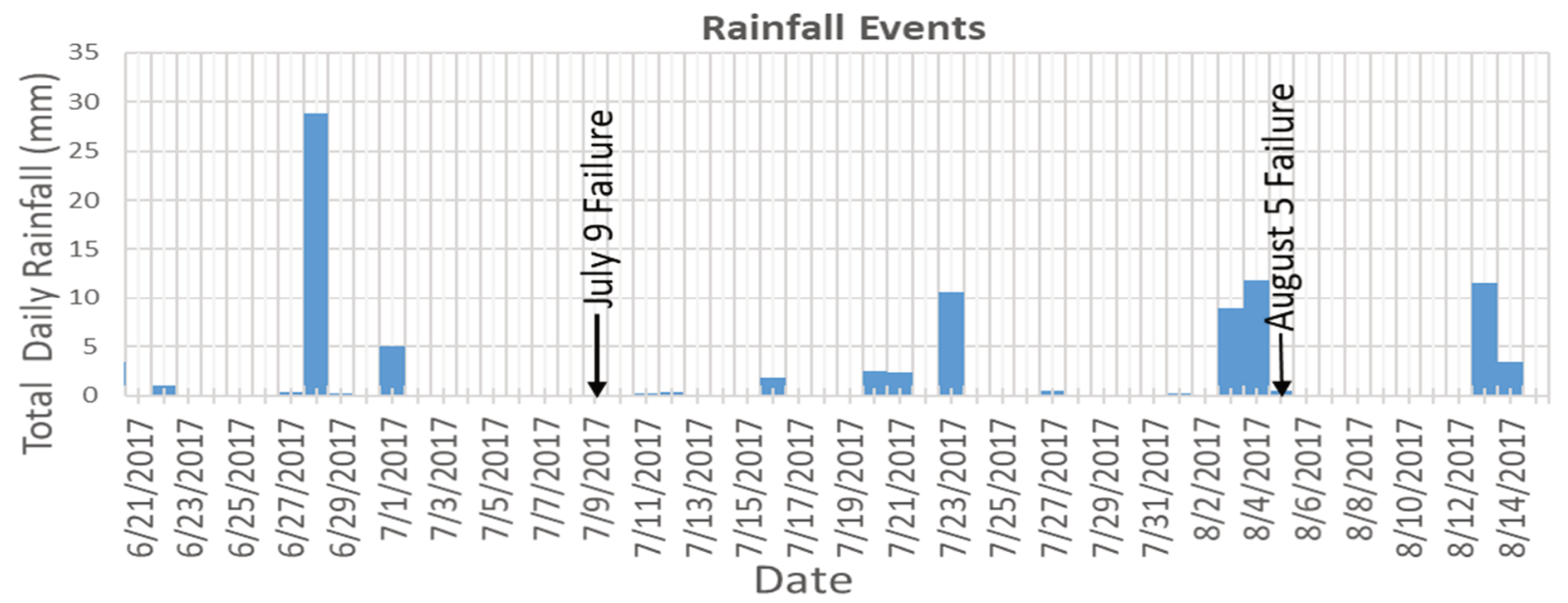

Figure 6 Rainfall events preceding failures

\subsection{Radar monitoring of slope}

The second failure on 5 August 2017 was identified in advance based on slope deformation (Figures 7(a) and $7(b))$, velocity and inverse velocity trends. Figure 8 presents an inverse velocity graph that shows an accelerating trend developing around 31 July and possibly as early as 29 July, leading up to the 5 August failure. 

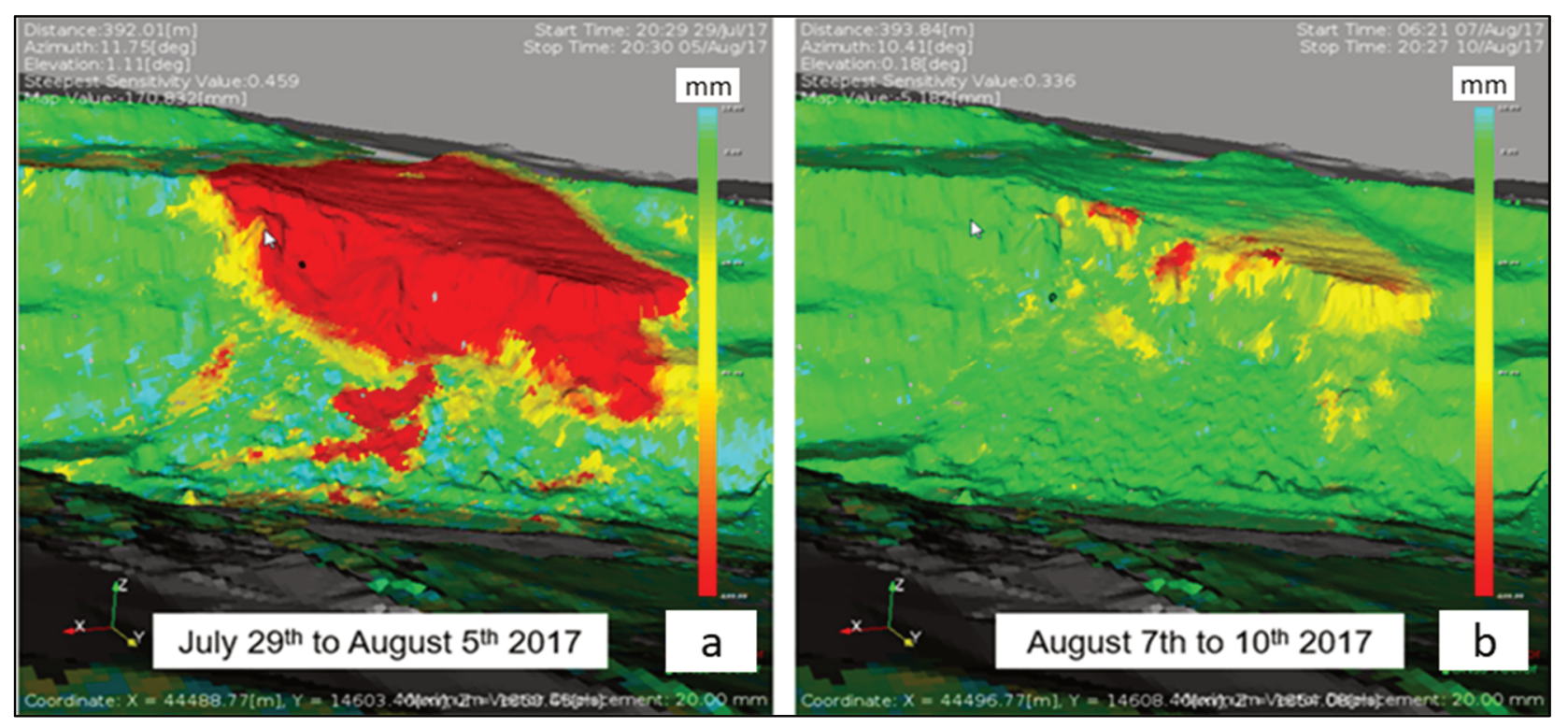

Figure 7 Radar slope displacement monitoring (a) Before; and (b) Following the 5 August failure

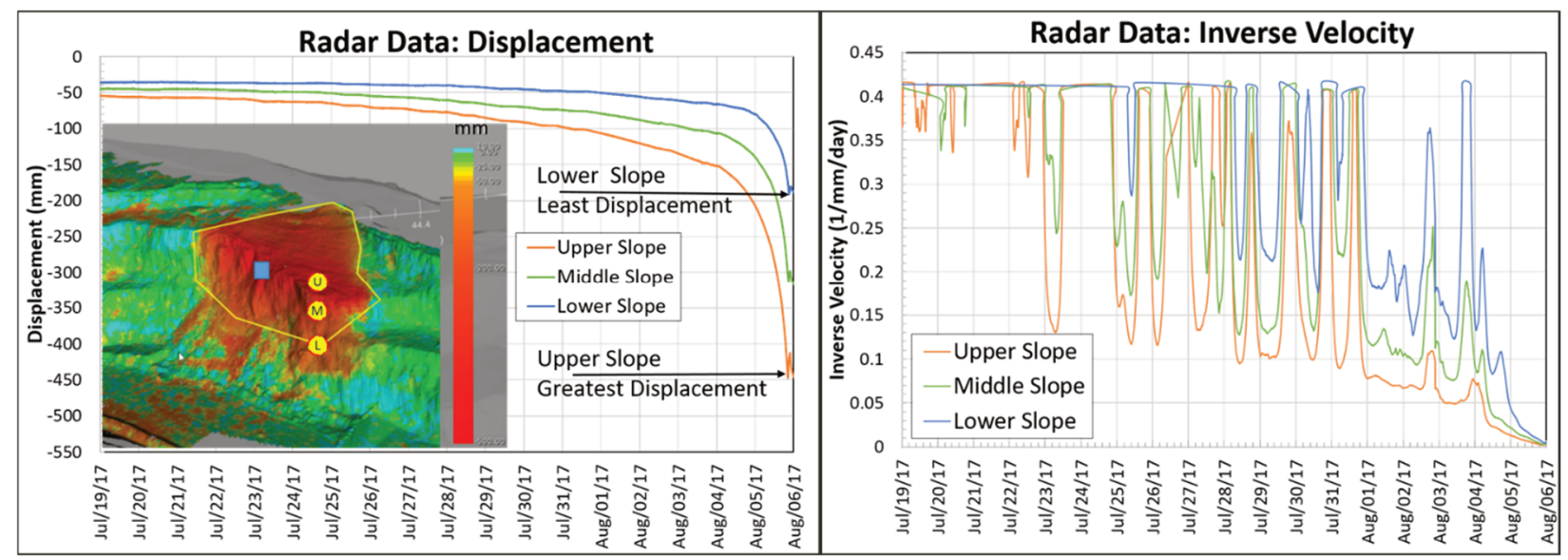

Figure 8 Displacement and inverse velocity plot

\subsection{Dip meter data}

Available subsurface structural data consist of dip meter data collected by geophysical logging of exploration boreholes through the pit area. Dip meter data are typically limited in usefulness as they are predominantly related to bedding orientation and do not include any other important structural features. Since the highwall failure is very much related to the orientation of the stratigraphy, the data provided a better understanding of the consistency of bedding orientations behind the wall.

The dip meter data indicate the stratigraphy is generally inclined to the south-southwest at around $55^{\circ}$. Since toppling failure typically does not occur at angles less than 60 to $65^{\circ}$, this suggests that there were additional factors that contributed to the 9 July 2017 failure.

\subsection{Surface mapping data}

Following the failure, a senior structural geologist visited the site and mapped two faults dipping to the north and striking at an oblique angle into the highwall slope. The faults are located just behind the design bench face of the lower bench in the 9 July 2017 failure area.

Bedding orientations were also obtained and suggested the bedding in the immediate vicinity of the failure ranged in dip from 60 to $75^{\circ}$ which is more consistent with the potential for toppling. A local steepening 
(possibly related to the faulting) is believed to have existed, resulting in shallower bedding at the toe and steeper bedding at the crest.

\section{$6 \quad$ Modelling methodology}

To capture the complexity of the remaining hazards to re-entry, different modelling methods were used.

\subsection{Finite element analysis}

A back-analysis of the failure progression was completed using the finite element modelling program RS2 ${ }^{\mathrm{TM}}$ (Rocscience Inc. 2019). The purpose of the back-analysis was to confirm the ability of the finite element modelling to reasonably predict future slope performance for the development of a re-entry plan. Limit equilibrium methods were not used as the toppling failure mechanism could not be reasonably represented using such methods.

\subsection{Rockfall analysis}

The review of the failure process identified that a rockfall hazard remained in the eastern area of the failure zone. To support the plan for re-entry, a rockfall assessment of the existing rock slope and talus cone associated with the eastern end of the failure was undertaken using RocFall ${ }^{\mathrm{TM}}$ (Rocscience Inc. 2018). A back-analysis was first completed to calibrate the rockfall model based on observed runout distances onsite, followed by forward modelling to develop design guidelines for construction of a rockfall containment berm at the toe of the slope.

\subsection{Runout assessment}

The potential for mass failure of the remaining potential toppling area at the western end of the failure zone was evaluated using the software Dan-W ${ }^{\mathrm{mM}}$ (Hungr 2003). The software models the runout behaviour of rapid landslides in 2D based on a specified geometry and material properties. A back-analysis was used to calibrate the model based on the rapid 9 July 2017 initial failure, and a forward analysis was used to evaluate the potential runout modality of the potential west toppling area and to guide the estimation of appropriate height and location of a runout berm at the toe of the slope to protect the work area from the failure hazard in the western end.

\section{$7 \quad$ Material properties}

Geomechanical rock mass properties were inferred from Tetra Tech's experience working with similar rock types and from geotechnical investigations at nearby open pits. Limited laboratory testing data were available. Elastic properties were estimated based on full waveform sonic borehole geophysical surveys. Values for disturbed Young's modulus were estimated using the Hoek-Diederichs (2005) method.

Table 1 presents the Mohr-Coulomb properties that were used for modelling the coal seams and failed debris. Table 2 presents the Hoek-Brown rock mass strength properties used for modelling the sedimentary units, and the inter-fault material. Table 3 presents the discontinuity shear strengths for the bedding and orthogonal joint set based on direct shear laboratory strength testing from a nearby project. Discontinuities are typically modelled without cohesion, however, cohesion was required for numerical stability, as summarised in Table 3. 
Table 1 Estimated Mohr-Coulomb material properties for modelling

\begin{tabular}{lllllll}
\hline $\begin{array}{l}\text { Geological } \\
\text { unit }\end{array}$ & Description & $\begin{array}{l}\text { Unit weight } \\
\left(\mathrm{KN} / \mathbf{m}^{3}\right)\end{array}$ & $\begin{array}{l}\text { Geomechanical properties } \\
(\mathbf{k P a})\end{array}$ & $\begin{array}{l}\text { Friction } \\
\text { angle }\left(^{\circ}\right)\end{array}$ & $\begin{array}{l}\text { Undisturbed } \\
\text { Young's modulus } \\
(\mathbf{G P a})\end{array}$ & $\begin{array}{l}\text { Poisson's } \\
\text { ratio }\end{array}$ \\
\hline $\begin{array}{l}\text { Rider seam } \\
\text { Jewel seam }\end{array}$ & Coal seam & 14 & 0 & 28 & 2 & 0.37 \\
$\begin{array}{l}\text { Failed } \\
\text { material }\end{array}$ & $\begin{array}{l}\text { Talus cone of } \\
\text { failed debris }\end{array}$ & 20 & 0 & 30 & 2 & 0.34 \\
\hline
\end{tabular}

Table 2 Estimated Hoek-Brown material properties for modelling

\begin{tabular}{|c|c|c|c|c|c|c|c|}
\hline \multirow[b]{2}{*}{ Domain } & \multirow[b]{2}{*}{ Description } & \multicolumn{6}{|c|}{ Geomechanical properties } \\
\hline & & $\begin{array}{l}\text { Unit } \\
\text { Weight } \\
\left(\mathrm{KN} / \mathrm{m}^{3}\right)\end{array}$ & GSI & $\begin{array}{l}\text { UCS } \\
\text { (MPa) }\end{array}$ & $\mathbf{m}_{\mathrm{i}}$ & $\begin{array}{l}\text { Young's } \\
\text { Modulus } \\
\text { (GPa) } \\
\text { undisturbed } \\
\text { (disturbed) }\end{array}$ & $\begin{array}{l}\text { Poisson's } \\
\text { ratio }\end{array}$ \\
\hline $\begin{array}{l}\text { Mountain Park } \\
\text { member }\end{array}$ & Sandstone & & 65 & 50 & 17 & $30(7.96)$ & 0.25 \\
\hline \multirow{2}{*}{$\begin{array}{l}\text { Grande Cache } \\
\text { member }\end{array}$} & Interbedded sediments & & 50 & 45 & 7 & $23(2.47)$ & 0.28 \\
\hline & Sandstone & & 65 & 50 & 17 & $30(7.96)$ & 0.25 \\
\hline $\begin{array}{l}\text { Torrens } \\
\text { member }\end{array}$ & Sandstone & 26 & 70 & 90 & 17 & $33(11.14)$ & 0.26 \\
\hline $\begin{array}{l}\text { Fault damaged } \\
\text { rock mass }\end{array}$ & $\begin{array}{l}\text { Disturbed Grande } \\
\text { Cache interbedded } \\
\text { sediments }\end{array}$ & & 40 & 45 & 7 & $23(1.34)$ & 0.28 \\
\hline
\end{tabular}

GSI = Geological Strength Index; UCS = uniaxial compressive strength

Table 3 Estimated discontinuity strengths for modelling

\begin{tabular}{llllll}
\hline Joint set & $\begin{array}{l}\text { Cohesion } \\
(\mathrm{kPa})\end{array}$ & $\begin{array}{l}\text { Peak friction } \\
\left.\text { Angle }^{\circ}\right)\end{array}$ & $\begin{array}{l}\text { Residual } \\
\text { friction } \\
\text { angle }\left({ }^{\circ}\right)\end{array}$ & $\begin{array}{l}\text { Shear } \\
\text { stiffness } \\
(\mathrm{GPa} / \mathrm{m})\end{array}$ & $\begin{array}{l}\text { Normal stiffness } \\
(\mathbf{3} \times \text { shear stiffness }) \\
(\mathrm{GPa} / \mathrm{m})\end{array}$ \\
\hline Bedding & $\begin{array}{l}100 \text { peak } \\
50 \text { residual }\end{array}$ & 31 & 29 & 3.9 & 11.7 \\
$\begin{array}{l}\text { Orthogonal } \\
\text { joint }\end{array}$ & $\begin{array}{l}100 \text { peak } \\
50 \text { residual }\end{array}$ & 39 & 34 & 4.7 & 14.1 \\
Fault & 0 & 20 & 17 & 1 & 3 \\
\hline
\end{tabular}

\section{Finite element analysis (RS2 ${ }^{\mathrm{TM}}$ )}

The rock mass was modelled as an elastic-plastic material using the material properties described above. A disturbance factor of $D=0.7$ was applied to the entire slope to account for heavy production blasting and 
the existing failed material. An in-plane horizontal to vertical stress ratio $k=1.5$ was assumed. A cross jointed joint network model was used to define the parallel bedding planes and orthogonal cross joints. The bedding planes are assumed to have infinite persistence while the orthogonal joints terminate against the bedding planes. The bedding was assigned a constant spacing of $3 \mathrm{~m}$ based on visual observation of obsequent scarps forming on bedding planes in the initial failure area at the crest of the slope. The cross joints were input as a random variable with a mean spacing of $3 \mathrm{~m}$ and a standard deviation of $2 \mathrm{~m}$. The model includes two faults at the slope toe, which were modelled as joint boundaries. Shear stiffness was estimated based on direct shear testing at nearby sites. The normal stiffness was estimated as three times the shear stiffness. The rock mass between the two faults is highly disturbed and was not assigned a joint network. The groundwater table was assumed to be $35 \mathrm{~m}$ above the pit floor (1,855 m elevation) for the 5 July 2017 failure based on seepage observations and elevated to ground surface for the analysis of the 5 August 2017 failure based on the weather data which indicated two days of rainfall preceding the failure. The modelled excavation stages progressed to match the mining sequence preceding the failure. The forward analysis incorporated a fully loaded Komatsu 830 haul truck to represent a worst-case truckload during unloading of the crest area. This was simulated using two $2 \mathrm{MN} / \mathrm{m}$ line loads spaced at $7 \mathrm{~m}$. Figures $9(\mathrm{a})$ and $9(\mathrm{~b})$ illustrate the models used to simulate the 9 July (initial) and 5 August (second) failures, respectively.
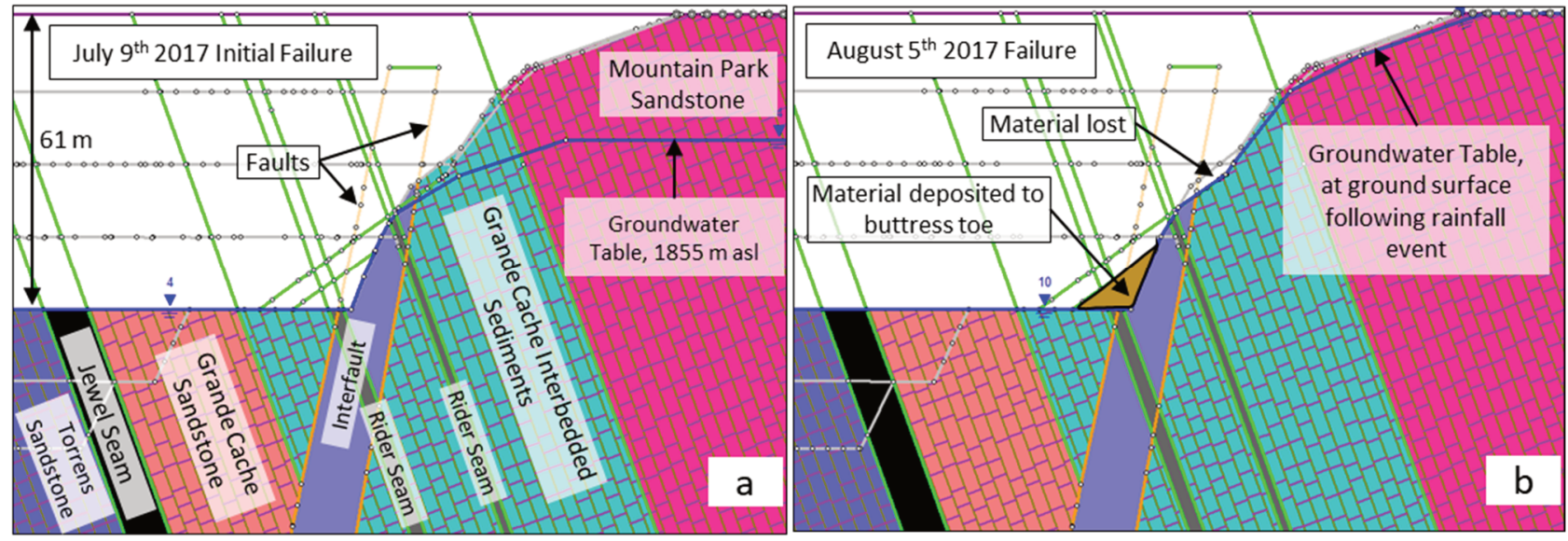

Figure 9 Models of the (a) 9 July 2017; and (b) 5 August 2017 failures

\subsection{Back-analysis}

The model was calibrated through a back-analysis of the 9 July (initial) and the 5 August 2017 (second) failures. The results of the back-analysis are consistent with the interpreted failure sequence, suggesting that the initial failure initiated by over-digging of the weak inter-fault material at the toe of the slope resulting in a circular failure within this material. The subsequent loss of confinement at the toe allowed toppling movement of the steeply dipping bedding and leading to the development of the obsequent faulting along bedding planes visible in the slope crest. The shear strength reduction (SSR) method was used to estimate the strength reduction factor (SRF) following the 9 July and 5 August 2017 failures, and for the slope profile at the time of the study. Table 4 summarises the results of the SSR back-analysis shown in Figures 10(a) and 10(b).

Table 4 Results of RS2 back-analysis

\begin{tabular}{ll}
\hline Slope configuration & Strength reduction factor \\
\hline Initial (9 July) failure & 0.8 \\
Second (5 August) failure & 0.9 \\
Buttressed slope (ongoing ravelling) & 1.2 \\
\hline
\end{tabular}




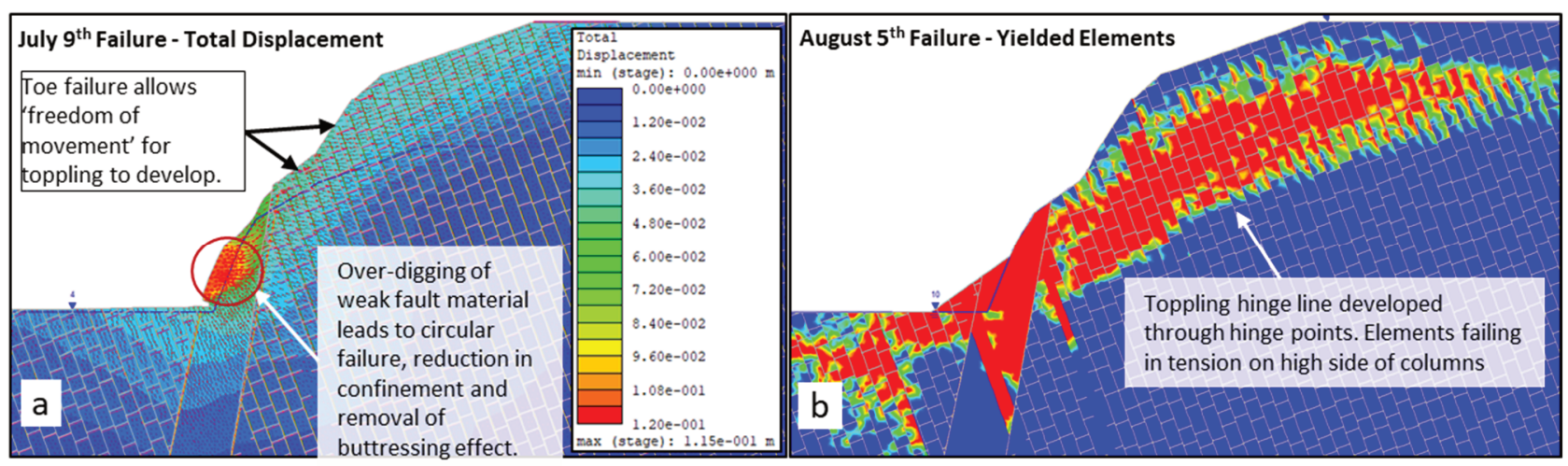

Figure 10 Results of RS2 back-analysis showing (a) circular failure initiating toppling on 9 July 2017 failure; and (b) Subsequent deep hinge line development during 5 August 2017 failure

The results of the SSR analysis indicate that the naturally buttressed slope following ongoing ravelling of material does not meet the design acceptance criteria (DAC) for the project. An SRF of 1.3 was targeted for design for re-entry below the unstable slope.

\subsection{Forward analysis and results}

Following the back-analysis, two re-entry strategies were evaluated, which are shown in Figures $11(a)$ and 11(b).

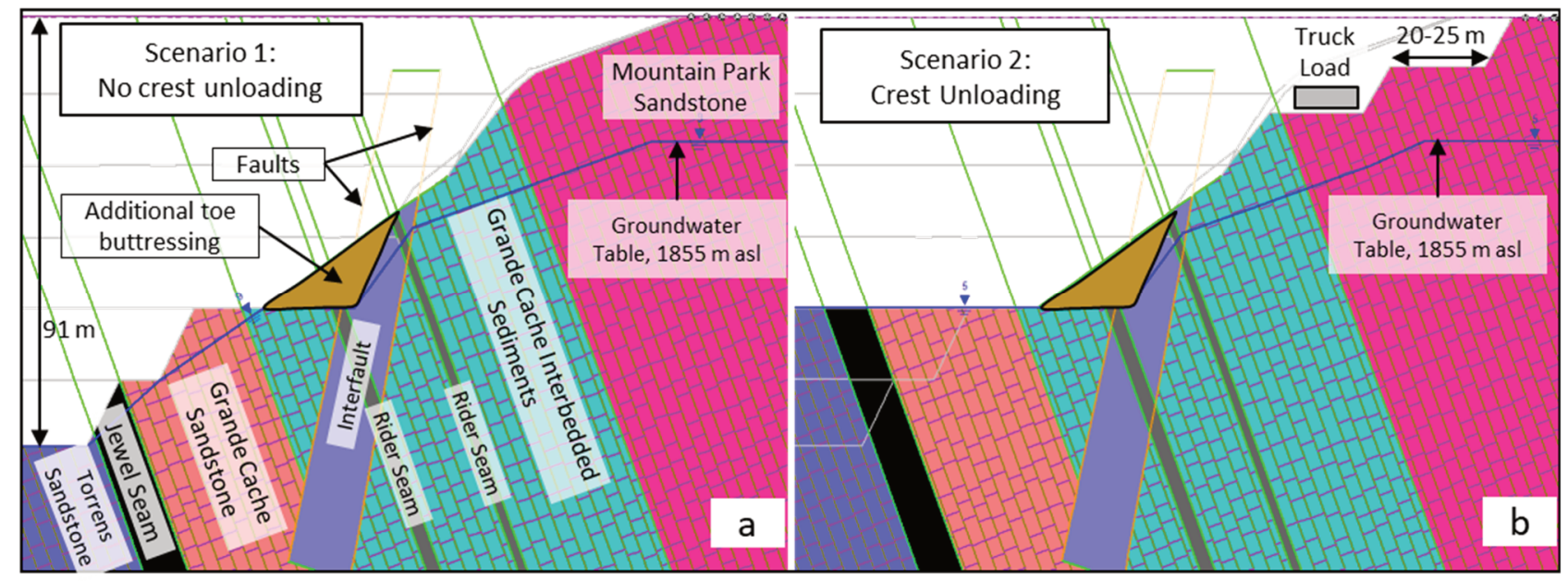

Figure 11 Modelled re-entry scenarios for (a) Scenario 1; and (b) Scenario 2

Re-entry Scenario 1 involves the construction of a rockfall deflection or containment berm at the toe of the failed slope, with no unloading of the crest area. An $8 \mathrm{~m}$ wide bench would separate the pit-side toe of the berm from the crest of the next bench. The east rockfall hazard and west toppling (mass runout) hazard would remain. A final $15 \mathrm{~m}$ high bench would be taken down to the $1,805 \mathrm{~m}$ elevation, followed by a sub-out of remaining coal in the final $1,805 \mathrm{~m}$ pit floor and down to approximately $1,790 \mathrm{~m}$ elevation during the sub-out retreat.

Re-entry Scenario 2 involves unloading of the crest by benching down through the failed material on two $10 \mathrm{~m}$ high, $20 \mathrm{~m}$ to $25 \mathrm{~m}$ wide benches. The objective would be to remove or force the failure of the west toppling hazard and to stabilise the slope by removing some of the failed crest. Following unloading, a rockfall containment berm would be constructed at the toe of the slope. An $8 \mathrm{~m}$ wide bench would separate the pit-side toe of the berm from the crest of the next bench. A final $15 \mathrm{~m}$ high bench would be taken down to $1805 \mathrm{~m}$ elevation, followed by a sub-out of remaining coal down to approximately $1,790 \mathrm{~m}$ elevation during the sub-out retreat. 
Table 5 summarises the modelling results of the forward SSR analyses of the two re-entry scenarios.

Table 5 Results of shear strength reduction analysis of re-entry scenarios

\begin{tabular}{|c|c|c|c|c|}
\hline $\begin{array}{l}\text { Re-entry } \\
\text { strategy }\end{array}$ & $\begin{array}{l}\text { Toppling } \\
\text { hazard } \\
\text { removed }\end{array}$ & $\begin{array}{l}\text { Bench width on } 1,820 \mathrm{~m} \\
\text { elevation }\end{array}$ & $\begin{array}{l}\text { Slope (bottom } \\
\text { elevation) }\end{array}$ & $\begin{array}{l}\text { Strength } \\
\text { reduction } \\
\text { factor }\end{array}$ \\
\hline \multirow{4}{*}{ Scenario 1} & \multirow{4}{*}{ No } & $11 \mathrm{~m}$ (berm $+2 \mathrm{~m}$ wide bench) & Sub-out (1790) & $<1$ \\
\hline & & \multirow{2}{*}{$15 \mathrm{~m}$ (berm + $6 \mathrm{~m}$ wide bench) } & Final Bench (1805) & 1.1 \\
\hline & & & Sub-out (1790) & $<1$ \\
\hline & & $17 \mathrm{~m}$ (berm $+8 \mathrm{~m}$ wide bench) & Sub-out (1790) & $<1$ \\
\hline \multirow{2}{*}{ Scenario 2} & \multirow{2}{*}{ Yes } & \multirow{2}{*}{$17 \mathrm{~m}$ (berm $+8 \mathrm{~m}$ wide bench) } & Final Bench (1805) & 1.3 \\
\hline & & & Sub-out (1790) & 1.1 \\
\hline
\end{tabular}

The modelling of Scenario 1 showed that continued mining to the final 1,790 m elevation could potentially re-initiate the toppling failure of the slope.

The modelling of Scenario 2 indicated that benching down through the failed material of the crest area, combined with removal of the toppling hazard, and development of a rockfall containment berm on 1,820 $\mathrm{m}$ platform would result in an overall slope meeting a DAC ( $S R F \geq 1.3)$ for mining to the $1,805 \mathrm{~m}$ elevation, and SRF of 1.1 during the final sub-out which would be completed using a retreat-mining method.

Scenario 2 was selected based on the SSR analysis results. Subsequent analysis and design focussed on estimating the appropriate size and location of the rockfall deflection/containment berm to be constructed at the toe of the slope. For the west toppling hazard area, it was assumed that during benching down of the upper slope it was not possible to fully remove the toppling hazard, and the berm in the west area was designed accordingly and conservatively to accommodate a mass runout event.

\section{$9 \quad$ Rockfall analysis (RocFall ${ }^{\mathrm{TM}}$ )}

\subsection{Model set-up and inputs}

Analysis of rockfall trajectories, velocity and energy was completed using the software RocFall (Rocscience Inc. 2018). A back-analysis was used to calibrate the model input parameters against the observed rockfall travel. A forward analysis was completed following model calibration. The analysis was performed using the Rigid Body method, which models the mass, size, and shape of each block and accounts for the falling rocks' interaction with irregularities of the slope profile using a slope roughness variability. Two cross sections were selected: one through the eastern rockfall hazard area and one through the western toppling hazard area. The slope was divided into five materials for modelling as shown in Figures 12(a) and 12(b). These materials were: bedrock at the crest of the slope, fine to medium talus in the upper talus material, medium to coarse talus, coarse to very coarse talus in the lower talus material, and compacted soil to rock at the toe of the slope. Angular sub-orthogonal block sizes of 1, 2, 3 and $4 \mathrm{~m}$ in diameter were used. A seeder was placed near the crest of the slope to simulate toppling of discrete blocks, and an initial rotational velocity of $-20(\% / \mathrm{s})$ was applied. 


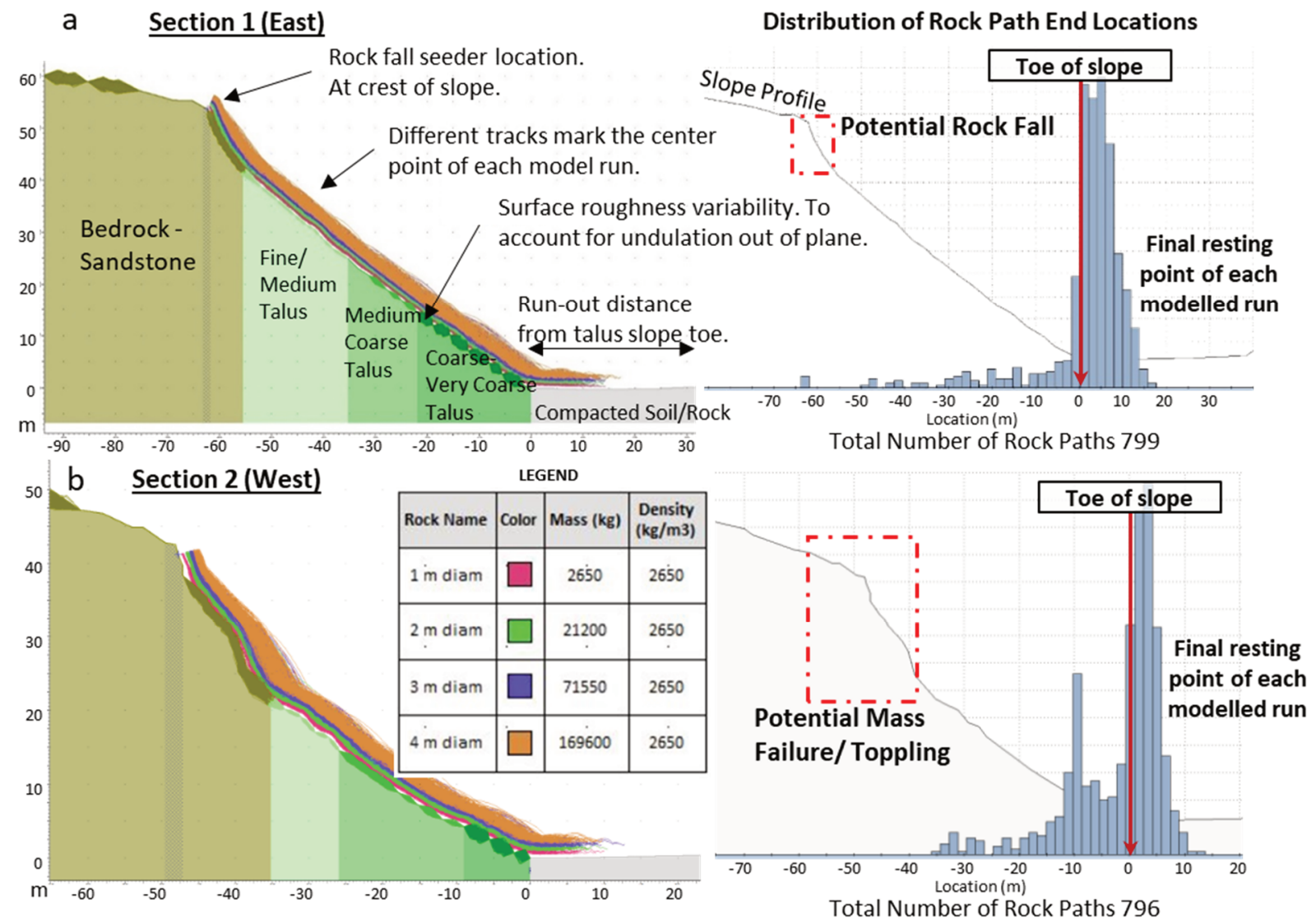

Figure 12 Rockfall travel distance back-analysis for (a) East; and (b) West areas

\subsection{Back-analysis}

The material properties were modified using an iterative approach to match the observed debris scatter and rockfall runout at the toe of the slope. To correlate the rockfall models with observed conditions and to act as a reference point for berm sizing and location, the toe of the talus slope was set to $0 \mathrm{~m}$ on the model $\mathrm{x}$-axis. Rockfall travel distances (or end locations) are reported relative to the talus slope toe. Figures 13(a) and 13(b) illustrate graphical representation of the rollout distances. The results indicate the majority of modelled rockfalls terminate within $10 \mathrm{~m}$ of the talus slope toe, which is consistent with observations from photographs. It is difficult, however, to determine, and thus correlate, the exact proportion of falling rocks terminating within the talus slope from photographs. Therefore, the models are calibrated with the maximum rollout distances (approximately 10 and $13 \mathrm{~m}$, respectively) identified from scaled photographs.

\subsection{Forward analysis and results}

The calibrated model was used to assess the effectiveness of a rockfall containment berm at the toe of the slope to retain discrete rockfalls and travel distance from the slope. A target performance of $95 \%$ retention was set and three berm heights were evaluated: 1.5, 2, and $3 \mathrm{~m}$ high. The efficiency of each berm height was assessed to determine the optimum berm height and centre line location (offset from toe of slope) to achieve $95 \%$ retention, while minimising the berm footprint to optimise coal recovery. Figures $13(a)$ and 13 (b) present the results of this analysis for the different berm heights. Berms placed further from the talus toe would require less material and time to construct but would encroach on the remaining coal resource; berms close to the toe would require more material and larger equipment to construct but would allow better access to the remaining coal. 

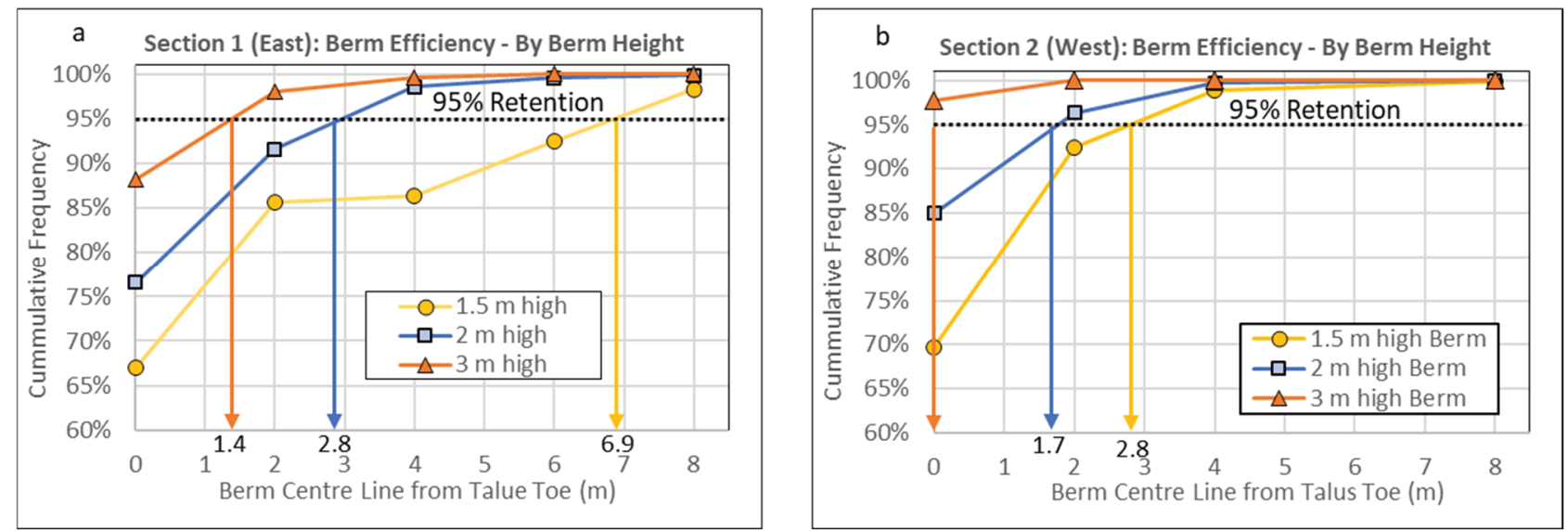

Figure 13 Results of rockfall travel to optimise berm geometry for (a) East; and (b) West areas

\section{DAN-W ${ }^{\mathrm{TM}}$ debris runout assessment}

The west toppling hazard was assessed with a debris runout analysis using Dan- $\mathrm{W}^{\mathrm{TM}}$ and calibrated against observed conditions. Dan-W is a geotechnical software tool used to model post-failure motion of rapid landslides. The results were used to assess a suitable size and position of a berm to retain a potential debris runout if the remaining toppling hazard were to fail.

\subsection{Model set-up and inputs}

Two cross sections were selected for analysis. The first section was through the 9 July 2017 (initial) failure and was used for a back-analysis for model calibration. The second section was through the west toppling hazard area and was used in a forward analysis to develop design criteria for a runout berm. The slope profile was based on the provided survey data. The calibration was completed using the two most common rheology models: frictional rheology and Voellmy rheology. Inputs to the frictional rheology are the basal friction angle, internal friction angle, and pore pressure coefficient $(\mathrm{Ru})$. Inputs to the Voellmy rheology are the frictional coefficient, turbulence coefficient, and the internal friction angle. The Voellmy rheology does not include pore pressure input. Therefore, the presence of groundwater is simulated by adjusting the friction angle by an equivalent percentage of the Ru coefficient used in the frictional rheology. The unit weight of the failed mass was assumed to be $20 \mathrm{kN} / \mathrm{m}^{3}$, based on estimates of in situ density and a bulking factor. The failure size and shape were defined explicitly, based on pre- and post-failure topographic surveys.

\subsection{Back-analysis}

A back-analysis was used to calibrate the runout distance of the modelled failure mass with the observed runout from the 9 July 2017 (initial) failure. Calibration models were run using the frictional and Voellmy rheologies varying the basal friction angle between 30 and $38^{\circ}$. Models were assumed to be dry (i.e. Ru=0).

The back-analysis determined that the runout distance and shape of the failed material matches best when using the Voellmy rheology with a frictional coefficient of $0.65\left(33^{\circ}\right.$ ), internal friction angle of $36^{\circ}$ (based on the angle of repose of the talus cone) and a turbulence coefficient of $500 \mathrm{~m} / \mathrm{s}^{2}$, as shown in Figure 14 . The Voellmy rheology produces a less elongated nose of the debris deposit compared to the frictional rheology. Vertical slices resulted in a more fluid-like behaviour of the failed mass; normal slices were more representative of the actual behaviour. The sensitivity to the internal friction angle is low, however, the sensitivity to the pore pressure coefficient $(\mathrm{Ru})$ is high. 

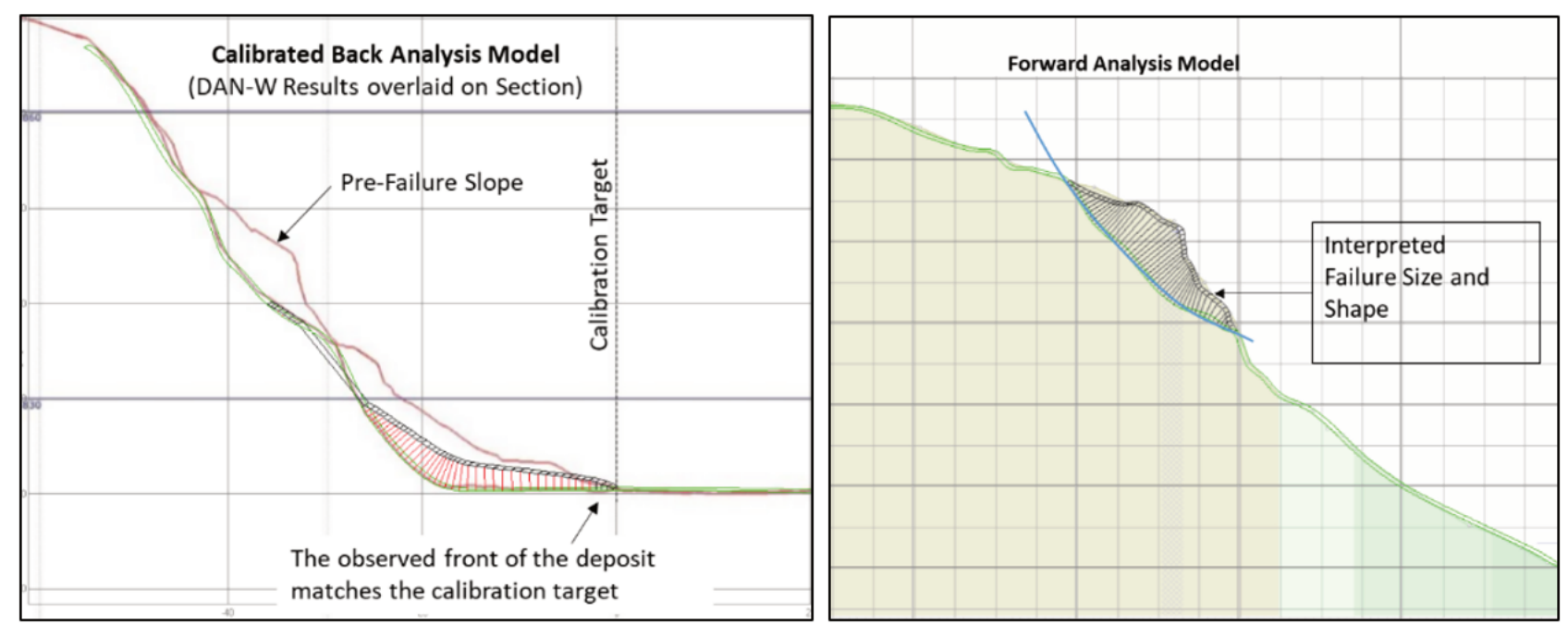

Figure 14 Calibrated debris runout back-analysis model of (a) 9 July 2017 failure; and (b) Forward analysis model

\subsection{Forward analysis and results}

Following the back-analysis, a forward analysis was completed to evaluate the potential for a mass failure of the western toppling hazard to over-top a containment berm at the toe of the slope. The results from the analysis were used to develop effective berm size and placement. The analysis used available topographic surveys and aerial photographs to estimate a pre- and post-failure slope. The failed mass shape included a concave base and an inflection point. The inflection point allowed the failed mass to simulate the toppling motion as best as possible. Figure 15 presents the results of the two base cases.
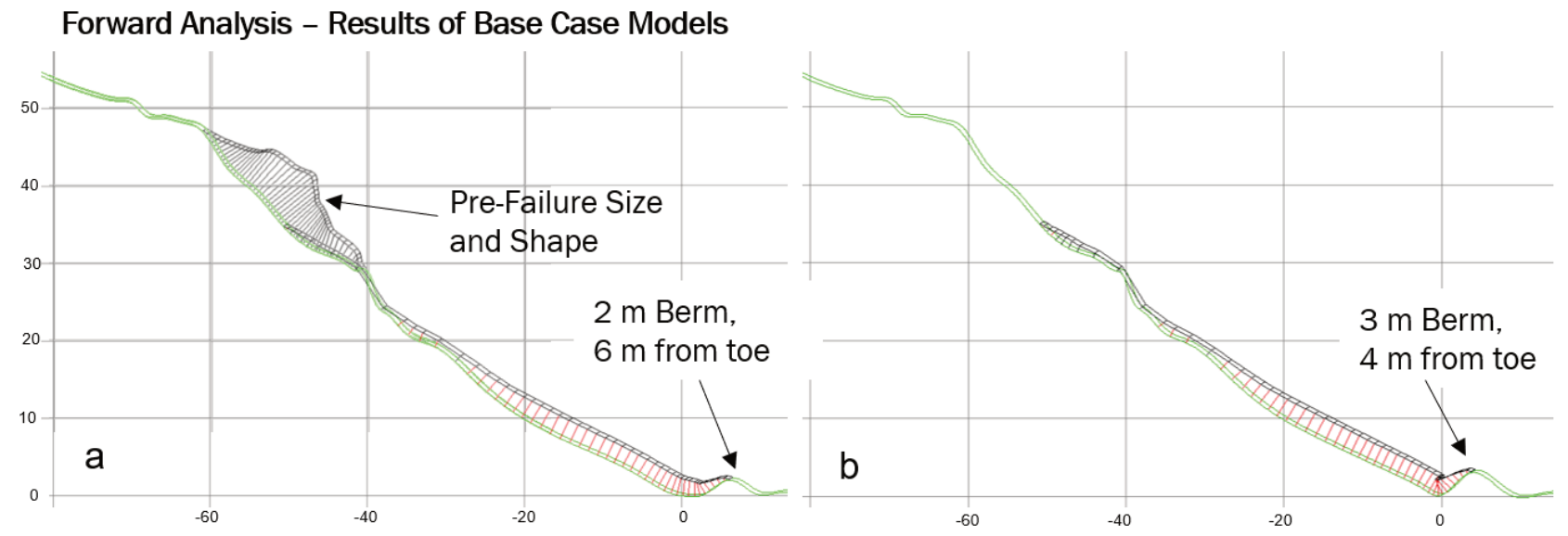

Figure 15 Summary of forward analyses for base cases (a) $2 \mathrm{~m}$ berm; $6 \mathrm{~m}$ from toe; and (b) $3 \mathrm{~m}$ berm, $4 \mathrm{~m}$ from toe

A groundwater sensitivity case to simulate a partially saturated slope was considered. This was accomplished by reducing the internal friction angle by $10 \%$ from 33 to $30^{\circ}$, equivalent to a Ru value of 0.1 or $20 \%$ saturation. Since the results are sensitive to the failure shape, a sensitivity case with a pre-failure mass having a smooth, straight bottom was considered. The results of the forward analysis are presented in Table 6 .

The modelling results suggest that construction of a containment berm at the toe of the slope below the west toppling hazard would be effective for containing debris runout from a potential mass failure with either: a $2 \mathrm{~m}$ high berm at $6 \mathrm{~m}$ from the failure toe, or a $3 \mathrm{~m}$ high berm at $4 \mathrm{~m}$ from the toe. Groundwater and failure shape sensitivity cases suggested a $3 \mathrm{~m}$ berm at $10 \mathrm{~m}$ from the toe or a $3 \mathrm{~m}$ berm at $16 \mathrm{~m}$ from the toe, respectively, would be needed to contain the runout. Figure 16 illustrates these configurations. 
Table 6 Summary of forward analysis

\begin{tabular}{lllll}
\hline Case & $\begin{array}{l}\text { Berm } \\
\text { height }(\mathbf{m})\end{array}$ & $\begin{array}{l}\text { Centre line Berm } \\
\text { distance from toe }(\mathbf{m})\end{array}$ & $\begin{array}{l}\text { Material } \\
\text { retained? }\end{array}$ & $\begin{array}{l}\text { Front } \\
\text { displacement }(\mathbf{m})\end{array}$ \\
\hline 2 & 8 & Yes & 7.2 \\
& & 6 & Yes & 6.1 \\
& & 4 & No & 8.7 \\
Base case & 3 & 8 & Yes & 6.1 \\
& & 6 & Yes & 5.0 \\
& 4 & Yes & 3.8 \\
& & 3 & No & 8.3 \\
$\begin{array}{l}\text { Groundwater } \\
\text { sensitivity case }\end{array}$ & 3 & 10 & Yes & 10.0 \\
$\begin{array}{l}\text { Failure shape } \\
\text { sensitivity case }\end{array}$ & 3 & 16 & Yes & 15.8 \\
\hline
\end{tabular}

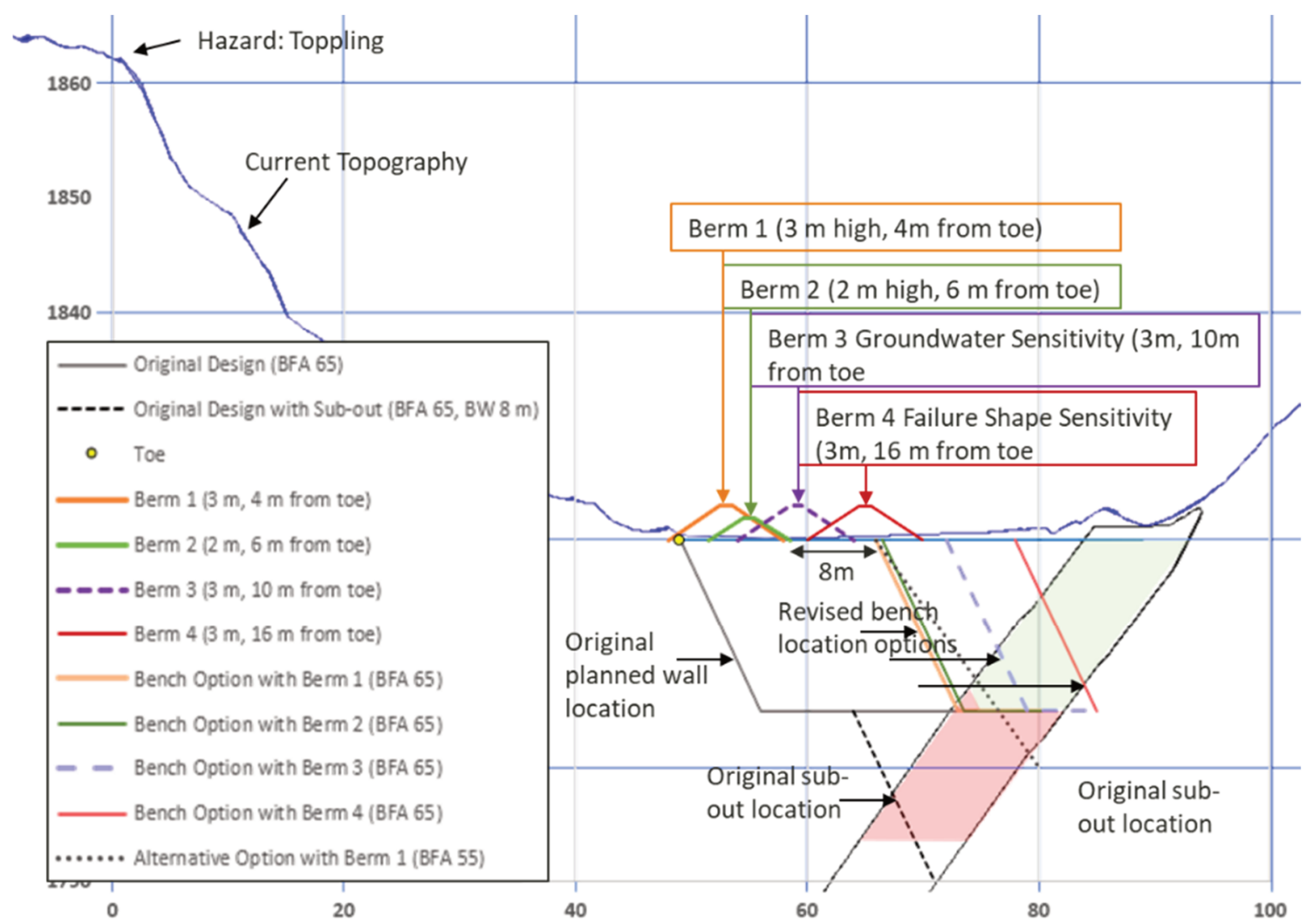

Figure 16 Options for debris runout berm geometry and location

\section{Summary and conclusions}

The highwall failure in the $\mathrm{H} 3 \mathrm{Pit}$ resulted in the suspension of mining until a practical, fit-for-purpose re-entry strategy could be developed that could be safely and reliably be implemented. The development of the strategy required the consideration of three potential failure mechanisms: re-initiation of toppling and 
overall slope instability, rockfall from the eastern area of the failure, and mass toppling failure and runout from the western area of the failure.

\subsection{Overall slope stability}

The results of the finite element assessment of overall slope stability indicated that the slope following the failure was marginally stable and did not meet the DAC of 1.3 to allow re-entry to the area. Two options which included benching down of the upper slope coupled with the development of rockfall containment and runout control berms at the toe of the slope were developed. The results of the modelling suggest that toppling of the upper slope could be re-initiated. To meet an acceptable DAC, an unloading bench at the crest in the western portion of the failed highwall was required.

\subsection{Rockfall analysis}

The east rockfall hazard area was assessed using a rockfall analysis to provide guidance on potential berm sizing and location to achieve a target of $95 \%$ retention of the modelled runs, suggesting either a $2 \mathrm{~m}$ high berm at $4 \mathrm{~m}$ from the toe or a $3 \mathrm{~m}$ high berm at $3 \mathrm{~m}$ from the toe can achieve this.

\subsection{Runout analysis}

The west toppling hazard area was assessed using a mass runout analysis to provide guidance on potential runout berm sizing and location. The analysis showed that a runout berm at the toe of the toppling area could be effective for containing runout from a potential mass failure, with the following configurations: a $2 \mathrm{~m}$ high berm at $6 \mathrm{~m}$ from the toe; or a $3 \mathrm{~m}$ high berm at $4 \mathrm{~m}$ from the toe. Groundwater and failure shape sensitivity cases suggested a $3 \mathrm{~m}$ berm at $10 \mathrm{~m}$ from the toe or a $3 \mathrm{~m}$ berm at $16 \mathrm{~m}$ from the toe, respectively, would be needed to contain the runout.

\subsection{Implementation of re-entry strategy}

Following the slope stability, rockfall, and runout assessments, the re-entry strategy was implemented. Prior to development of the re-entry strategy, the radar unit was set on top of footwall slope across from toppling failure, pointing directly at the failed slope. Two $10 \mathrm{~m}$ high benches were developed to unload at the crest of the slope. The first bench unloaded the crest at the 1,870 $\mathrm{m}$ elevation and the second bench unloaded the crest at the $1,860 \mathrm{~m}$ elevation. The bench widths were 20 to $25 \mathrm{~m}$. During benching and unloading of the upper slope, removal of the toppling area was achieved. Prior to mining at the toe, a rockfall and runout deflection berm were established, with side slopes of approximately $1.5 \mathrm{H}: 1 \mathrm{~V}$. An $8 \mathrm{~m}$ bench width was left between the pit-side toe of the berm and the bench crest. Following mining to the $1,805 \mathrm{~m}$ elevation, the sub-out was mined in a retreat-mining configuration.

\section{Acknowledgement}

The authors wish to acknowledge the assistance and contributions of Teck Coal Limited, Mr Peter Stacey of Stacey Mine Geotechnical Ltd., Mr Mathias Busslinger of BGC Consulting Ltd., and Mr Nigel Skermer of Tetra Tech. Mr. Stacey provided review at critical stages of the work, and guidance on important considerations that would not have been incorporated otherwise; Mr Busslinger and Mr Skermer were instrumental to overseeing the Dan-W analysis.

\section{References}

Hoek, E \& Diederichs, MS 2005, 'Empirical Estimation of Rock Mass Modulus', International Journal of Rock Mechanics \& Mining Sciences, vol. 43, pp. 203-215.

Hungr, O 2003, DAN W, version 1, computer software, O. Hungr Geotechnical Research Inc., Canada.

Rocscience Inc. 2018, RocFall, version 6.011, computer software, Rocscience Inc.

Rocscience Inc. 2019, RS2, version 9.030, computer software, Rocscience Inc. 